\title{
EGU21-5912
}

https://doi.org/10.5194/egusphere-egu21-5912

EGU General Assembly 2021

(c) Author(s) 2021. This work is distributed under

the Creative Commons Attribution 4.0 License.

\section{First airborne in situ SO2 observations of two coal-fired power plants in Serbia and Bosnia-Herzegovina: Potential for top-down emission estimate and satellite validation}

Theresa Klausner ${ }^{1}$, Heidi Huntrieser ${ }^{1}$, Heinfried Aufmhoff ${ }^{1}$, Robert Baumann ${ }^{1}$, Alina Fiehn ${ }^{1}$, KlausDirk Gottschaldt ${ }^{1}$, Pascal Hedelt ${ }^{2}$, Predrag $\| l i c ́^{5}$, Patrick Jöckel ${ }^{1}$, Sanja Mrazovac Kurilić ${ }^{3}$, Diego Loyola ${ }^{2}$, Ismail Makroum ${ }^{1}$, Mariano Mertens ${ }^{1}$, Zorica Podraščanin ${ }^{4}$, and Anke Roiger ${ }^{1}$

${ }^{1}$ Deutsches Zentrum für Luft- und Raumfahrt (DLR), Institut für Physik der Atmosphäre, Oberpfaffenhofen, Germany

${ }^{2}$ Deutsches Zentrum für Luft- und Raumfahrt (DLR), Institut für Methodik der Fernerkundung, Oberpfaffenhofen, Germany ${ }^{3}$ University Union-Nikola Tesla, Faculty of Ecology and Environmental Protection, Belgrade, Serbia

${ }^{4}$ University of Novi Sad, Department of Physics, Faculty of Sciences, Novi Sad, Serbia

${ }^{5}$ Institute for Protection and Ecology of the Republic of Srpska, Banja Luka, Bosnia-Herzegovina

Sulfur dioxide $\left(\mathrm{SO}_{2}\right)$ is known as a major air pollutant harmful to human health. Furthermore, it is a precursor gas of sulfate aerosol, which exerts a direct negative radiative forcing and thus leads to climate cooling. Anthropogenic $\mathrm{SO}_{2}$ sources are primarily associated with the combustion of sulfurrich fossil fuels. While the operation of flue gas desulfurization devices has led to large $\mathrm{SO}_{2}$ reductions in western Europe, a hotspot of anthropogenic $\mathrm{SO}_{2}$ sources remains in the Balkan region as recently observed from space by the TROPOMI instrument on the Sentinel-5P satellite. Large coal-fired power plants with no or only incomplete $\mathrm{SO}_{2}$ removal cause these high emissions.

Targeting these strong emitters, the DLR Falcon 20 aircraft was equipped with an isotopically online calibrated Chemical Ionization Ion Trap Mass Spectrometer (CI-ITMS) to obtain detailed in situ $\mathrm{SO}_{2}$ observations during the METHANE-To-Go-Europe aircraft campaign in autumn 2020. These $\mathrm{SO}_{2}$ measurements were complemented by in situ observations of greenhouse gases $\left(\mathrm{CO}_{2}, \mathrm{CH}_{4}\right)$, aerosol number concentrations, and other short-lived pollutants ( $\mathrm{CO}, \mathrm{NO}, \mathrm{NO}_{\mathrm{y}}$ ). Two flights, on November $2^{\text {nd }}$ and $7^{\text {th }} 2020$, focused on characterizing the pollution plumes downwind of two coalfired power plants located in Bosnia-Herzegovina (Tuzla) and Serbia (Nikola Tesla), respectively. These power plants belong to the ten strongest $\mathrm{SO}_{2}$ emitters in Europe, and according to the World Health Organization, both countries are among the most polluted ones in Europe.

We present a detailed analysis of the two DLR Falcon flights with strongly enhanced $\mathrm{SO}_{2}$ mixing ratios (exceeding $50 \mathrm{ppb}$ ), which were observed at low flight altitude $(<1 \mathrm{~km})$. Respective flight patterns were designed to allow for the evaluation of the TROPOMI vertical $\mathrm{SO}_{2}$ column densities, and both flights were performed during cloud-free conditions. The airborne measurements and satellite data will also be complemented by hourly ground-based $\mathrm{SO}_{2}$ measurements near both power plants. In addition, measurements are combined with state-of-the art model simulations from (i) the regional atmospheric chemistry climate model MECO(n); (ii) the atmospheric transport 
and dispersion model HYSPLIT; and (iii) the chemistry coupled Weather Research and Forecasting model WRF-Chem to improve the emission quantification of these power plants. 